\title{
Durabilitas Mortar Polimer Termodifikasi Alami dengan Amylum dan Bahan Tambah Madu
}

\author{
Nanda Isdian Prasetyo; Gerald Arsa Adhiyaksa Abiyoga; \\ Rr. M.I. Retno Susilorini dan Budi Santosa \\ e-mail: nandaisdain@gmail.com \\ Program Studi Teknik Sipil, Fakultas Teknik \\ Universitas Katolik Soegijapranata, Semarang
}

\begin{abstract}
The research aimed to investigate the durability of natural modified polymer mortar with amylum and honey admixture of aggressive environment that was modeled by 3 curing media, sea water, brakish water, and tidal flooding water. There were 855 specimens of mortar cubes with addition of amylum of 0,1\%,0,2\%, 1\%, 2\%, and 5\% and also honey of $0 \%, 0,03 \%$, and 0,03\%. All specimenswere cured and distributed into 3 curing medias for 7 , 14, and 28 days. The result of this research met conclusion that optimum compressive strength was achieved by specimen with composition 0,1\% amylum and 0,03\% honey that was cured by sea water.
\end{abstract}

\section{Pendahuluan}

Beton merupakan material yang paling banyak digunakan dalam konstruksi. Beberapa konstruksi seperti pondasi, pipa saluran, bahkan bendungan dan jalan raya dapat dibuat dari beton (Nugraha \& Antoni 2007).

Sifat durabiliras sangat diperlukan dalam beton. Sifat durabilitas yang dimaksud adalah sifat yang tahan terhadap pengaruh cuaca, zat kimia dan erosi. Beton dengan tingkat kekedapan yang tinggi merupakan beton yang baik. Yang dimaksud dengan kekedapan adalah air tidak dapat lewat pada benda tersebut (A.M. Neville \& J.J. Brooks, 1987). Akan tetapi beton tidak dapat kedap air secara sempurna (L.J. Murdock \& K.m. Brook, 1991).

Penelitian ini bertujuan untuk mengetahui durabilitas mortar polimer termodifikasi alami amylum dan bahan tambha madu terhadap air laut, air payau, dan air rob. Dalam pelaksanaannya, penelitian ini merupakan bagian dari penelitian payung "Strategi Adaptasi Masyarakat Pesisir Semarang dan Demak untuk Mitigasi Pengurangan Resiko Bencana Banjir dan Rob Akibat Perubahan Iklim" (Susilorini, et.al, 2017) yang memperoleh pendanaan dari INSINAS RPI (2017-2019) Kemristekdikti, Kontrak No. 35/INS/PPK/E/E4/2017-2019.

\section{Tinjauan Pustaka}

Beton terdiri dari campuran air, semen, agrergat halus dan agregat kasar yang bisa juga diberi bahan tambahan. Bahan campuran tambahan pada beton diberikan berdasarkan adanya hubugan antara sifat beton dengan sifat bahan tambahan pada saat beton sudah mengeras, hal ini ditujukan agar beton yang dihasilkan meningkat kualitasnya

\subsection{Durabilitas beton}

Dirabilitas beton merupakan kemampuan dari suatu material untuk menahan pengaruh dari luar yang dapat merusak material tersebut. (ACI 201.2R01, 2001). Berkurangnya durabilitas beton 
disebabkan oleh beberapa faktor, diantaranya pengaruh fisik, yaitu pelapukan oleh cuaca, pengaruh kimia yang disebabkan oleh campuran unsur kimia dalam beton dan pengaruh mekanis Ciri-ciri beton dengan durabilitas tinggi adalah (Saepudin, 2011):

1. Tahan terhadap pengaruh lingkungan

2. Memiliki umur yang panjang

3. Kepadatan struktur tinggi

4. Permeabilitas rendah

5. Porositas rendah

Kuat tekan itu sebanding dengan ketahanan abrasi dari beton Karena abrasi terjadi di permukaan, (ACI 201.2R-01, 2001). Penting agar kekuatan permukaan dimaksimalkan. Perlawanan Bisa ditambah dengan penggunaan getar dan topping, finishing teknik, dan prosedur perawatan (ACI 201.2R-01, 2001)

\subsection{Mortar Polimer}

Mortar merupakan material yang terdiri dari campuran agregat halus, air, dan bahan pengikat. (DY Simanullang, 2014).

Polimer jika dilihat dari konteks senyawa merupakan zat kimia yang terdiri dari gabungan molekul besar dengan karbon dan hydrogen sebagai molekul utama. Sedangkan jika dilihat dari konteks beton merupakan bahan penyusun dari bahan utama material mortar atau beton.

Jadi, mortar polimer adalah material bangunan yang dibentuk melalui proses rekayasa komposit beton klasik dan polimer (Arif, dkk, 2015).

\subsection{Madu}

Definisi madu menurut Food and Drug Administration (FDA) adalah produk alam yang dihasilkan oleh lebah dari nektar bunga yang dihisap dan dikumpulkan, kemudian diolah dan disimpan dalam sarang lebah untuk dimatangkan.

\subsection{Amylum}

Pati atau amilum adalah karbohidrat kompleks yang tidak larut dalam air, berwujud bubuk putih, tawar dan tidak berbau. Pati merupakan bahan utama yang dihasilkan oleh tumbuhan untuk menyimpan kelebihan glukosa (sebagai produk fotosintesis) dalam jangka panjang (Budianto, 2009).

\subsection{Bahan Tambah}

Bahan tambah merupakan bahan yang ditambahkan pada campuran beton. Tujuan memberikan bahan tambah untuk mengubah sifat beton dalam keadaan beton segar maupun sudah mengeras. (Anggraeni Syindi, 2014). Menuurut fungsinya, bahan tambah dibedakan menjadi beberapa contoh yaitu :

a. Mengurangi penggunaan air.

b. Memperlambat waktu ikat awal pada beton.

c. Mempercepat waktu ikat akhir pada beton.

\subsection{Kuat Tekan}

Parameter yang menunjukkan besarnya beban persatuan luas yang menyebabkan benda uji rusak oleh gaya tekan tertentu disebut kuat tekan. Kuat tekan menjadi parameter untuk menentukan mutu dan kualitas beton yang ditentukan oleh agregat, perbandingan semen dan perbandingan jumlah air. Pembuatan beton akan berhasil jika dalam pencapaian kuat tekan beton telah sesuai dengan yang telah direncanakan dalam mix design.

Kuat tekan mortar dan beton dalam tugas akhir ini diuji berdasarkan ASTM C39 dan dihitung berdasarkan formula sebagai berikut: $\sigma=\frac{\mathrm{P}}{\mathrm{A}}$

Keterangan:

$\boldsymbol{\sigma}=$ Tegangan normal, dalam hal ini kuat tekan $\left(\mathrm{N} / \mathrm{mm}^{2}=\mathrm{MPa}\right)$, $\mathrm{P}=$ Beban tekan $(\mathrm{N})$, $\mathrm{A}=$ Luas daerah yang tertekan $(\mathrm{mm} 2)$ 


\subsection{Komposisi Optimum}

Komposisi Optimum mortar tidak selalu dilihat dari kuat tekan mortar yang mencapai nilai tertinggi (nilai kuat tekan maksimal). Komposisi optimum dilihat dari nilai kuat tekan mortar, artinya nilai kuat tekan mortar pada umur 7, 14 dan 28 hari mengalami peningkatan kekuatan. Hal inilah yang disebut pula gradasi kuat tekan.

Komposisi optimum mortar juga berarti ekonomis, artinya penambahan atau kadar polimer alami (amylum karbohidrat dan madu) tidak banyak namun kenaikan kekuatannya signifikan. (Susilorini, et.al, 2017)

\section{Metode Penelitian}

\subsection{Diagram Alir}

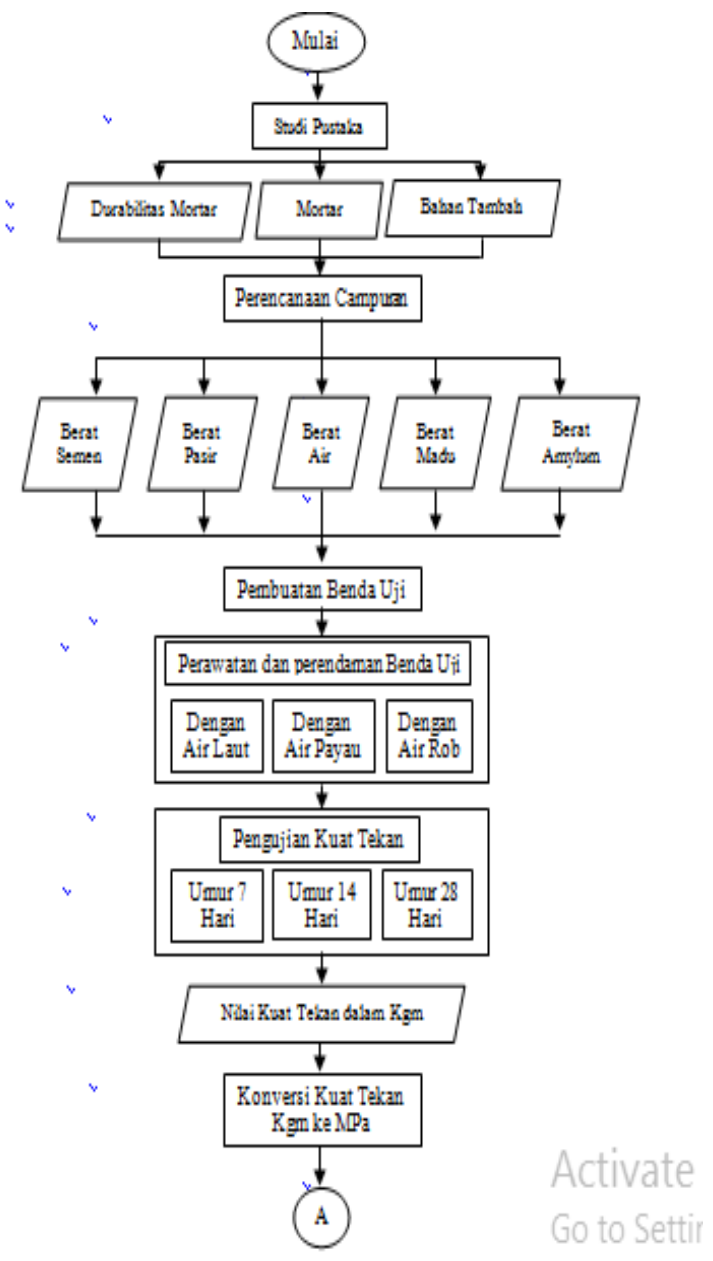

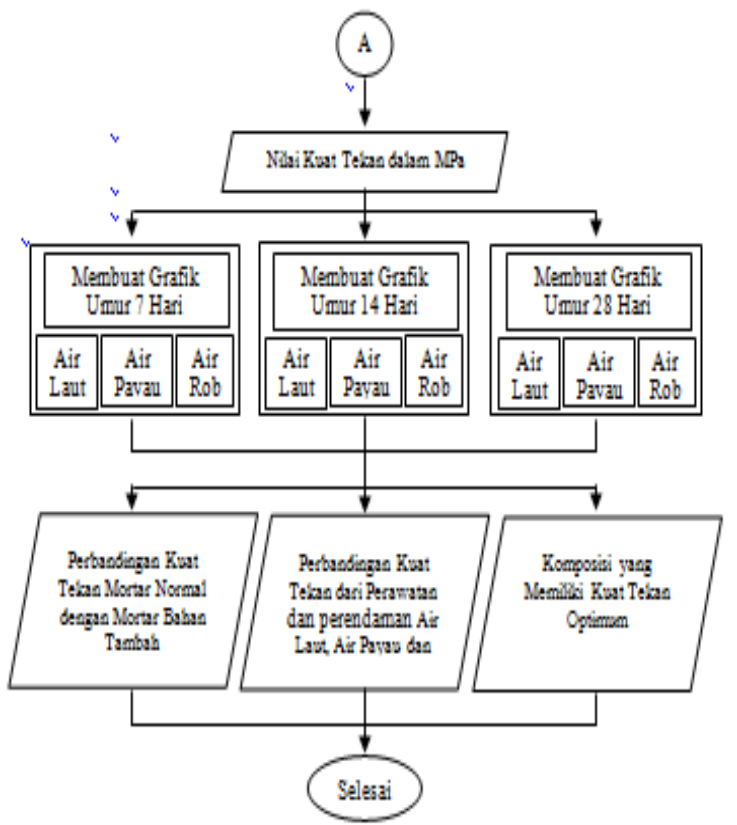

\subsection{Jalannya Penelitian}

Tinjauan pustaka dilakukan untuk menjelaskan beberapa teori penunjang yang diperlukan dalam menganalisis penelitian terutama yang berkaitan dengan durabilitas, mortar, dan bahan tambah madu maupun amylum.

Langkah awal yang dilakukan dalam percobaan utama adalah menentukan komposisi optimum untuk mortar. Komposisi bahan untuk mortar adalah semen : pasir : air = 1:1:0,6 (Susilorini, 2007). Berikut ini adalah tabel komposisi mix design untuk penelitian ini.

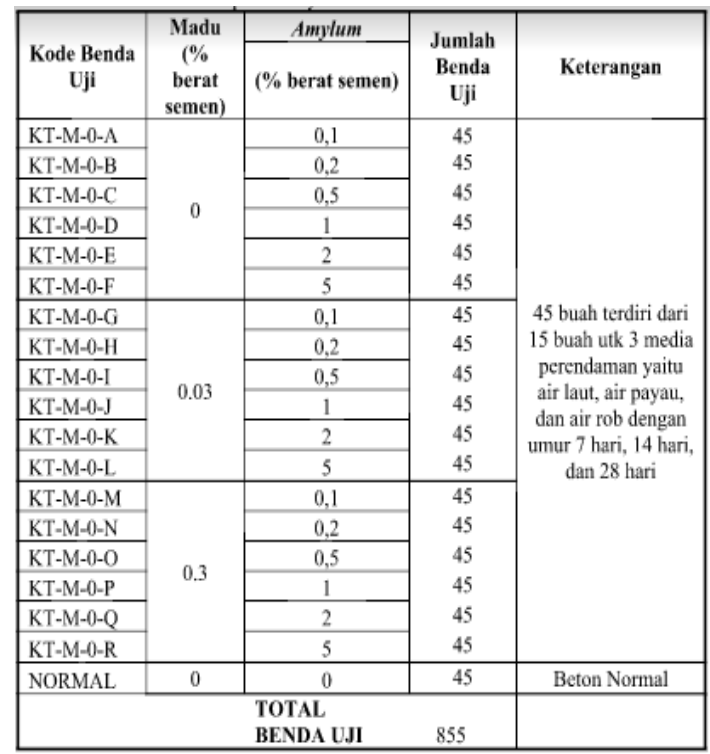


Tabel 3. 1 Tabel Komposisi Amylum Karbohidrat dan Bahan Tambah Madu

Bekisting kubus mortar dibuat dengan ukuran $5 \mathrm{~cm}$ x $5 \mathrm{~cm}$ x $5 \mathrm{~cm}$ sebanyak 15 buah tiap komposisi. Setelah alat dan bahan siap, dilakukan pembuatan benda uji kubus mortar polimer Amylum Karbohidratdan bahan tambah madu, selain itu juga dibuat benda uji kubus mortar kontrol (normal).

Benda uji berupa kubus mortar (Gambar 3.2) dengan dimensi panjang 5 $\mathrm{cm}$, lebar $5 \mathrm{~cm}$, dan tinggi $5 \mathrm{~cm}$ sesuai ASTM C109. Kuat tekan rencana $\left(f^{\prime} c\right)=$ $20 \mathrm{MPa}$ dan komposisi semen : pasir : air $=1: 1: 0,6$ (Susilorini, 2007).

Cara pembuatan benda uji kubus mortar:

a. Siapkan bekisting kubus mortar yang terbuat dari kayu dengan ukuran $5 \mathrm{~cm} \mathrm{x}$ $5 \mathrm{~cm} \times 5 \mathrm{~cm}$,

b. Siapkan semen, pasir, dan air dengan komposisi yang telah ditentukan. Siapkan tepung kanji dan madu,

c. Dosis tepung kanji dan madu diambil sekian persen dari kebutuhan semen,

d. Semen dan pasir diaduk dahulu sambil dituang air sedikit demi sedikit,

e. Setelah adukan mortar terlihat cukup homogen, masukkan tepung dan madu atau hanya madu yang telah dicampur dalam air, lalu aduk kembali sampai benar-benar homogen,

f. Tuang adukan mortar tersebut ke dalam bekisting dengan ukuran yang telah ditentukan.

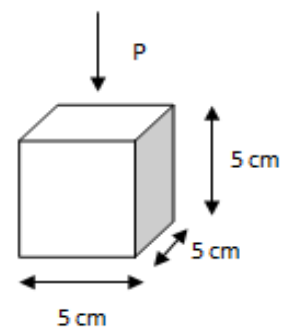

Gambar 3. 1 Benda Uji Kubus Mortar

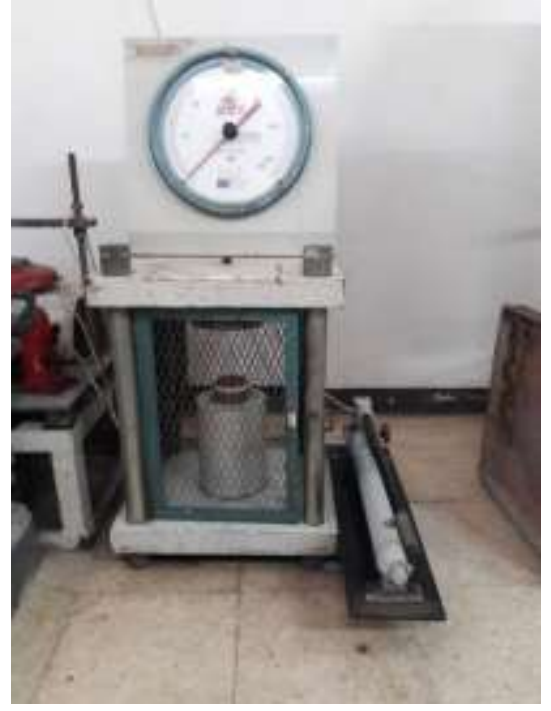

Gambar 3. 2 Compression Machine tipe CO-325.4 dengan kapasitas tekan $2000 \mathrm{KN}$

\subsection{Metode perawatan}

Perawatan benda uji dilakukan dengan cara merawat benda uji dalam 3 media perawatan yang berbeda, yaitu:air laut, air payau dan air rob. Tujuan perawatan benda uji untuk mengetahui pengaruh perawatan yang akan diuji dengan kuat tekan benda uji untuk mendapat fungsi lama waktu perawatan dengan kekuatan tekan benda uji. Benda uji dirawat selama 3 hari, 10 hari, dan 24 hari untuk umur masing-masing 7 hari, 14 hari, dan 28 hari. Setelah dirawat, benda uji dianginanginkan 2 hari kemudian di uji kuat tekan.

\subsection{Pengujian benda uji}

Dalam penelitian ini menggunakan metode pengujian uji kuat tekan sesuai ASTM C39. mortar yang telah dirawat dalam waktu tertentu dan telah diberi bahan tambah juga termodifikasi polimer. Uji kuat tekan dilakukan dengan alat compression machine seperti disajikan pada Gambar 3.2. 


\section{Hasil dan Pembahasan}

\subsection{Polimer Alami dan Bahan Tambah yang digunakan}

a. Pengujian Amylum

Hasil pengujian amylum disajikan pada Tabel 4.1 sebagai berikut.

Tabel 4. 1 Hasil Pengujian Laboratorium Amylum

\begin{tabular}{|c|c|c|c|c|c|c|c|}
\hline No & Kode & $\begin{array}{c}\text { Air } \\
\%\end{array}$ & $\begin{array}{c}\text { Abu } \\
\%\end{array}$ & $\begin{array}{c}\text { Lemak } \\
\%\end{array}$ & $\begin{array}{c}\text { Protein } \\
\%\end{array}$ & $\begin{array}{c}\text { Karbohidrat } \\
\%\end{array}$ & $\begin{array}{c}\text { Lignin } \\
\%\end{array}$ \\
\hline 1 & $\begin{array}{c}\text { Tepuag } \\
\text { Beras }\end{array}$ & 11,875 & 0,424 & 0,652 & 5,888 & 81,16 & 11,293 \\
\hline
\end{tabular}

\section{b. Pengujian Madu}

Pengujian madu yang digunakan sebagai bahan tambah pada campuran mortar disajikan pada Tabel 4.2 sebagai berikut.

Tabel 4.2 Hasil Pengujian Laboratorium Madu

\begin{tabular}{|c|c|c|c|c|c|}
\hline No & $\begin{array}{l}\text { Namia } \\
\text { Sampel }\end{array}$ & Parameter & Nilai & Samuan & Mesode \\
\hline \multirow{4}{*}{1} & \multirow{4}{*}{ Madu } & Fruktosa & 586 & \multirow{3}{*}{$\lg \mathrm{L}$} & \multirow{3}{*}{ HPLC } \\
\hline & & Glukoss & Negatif & & \\
\hline & & Sukgon & Nezatif & & \\
\hline & & Kadar Aír & $16,150=0,263$ & Ni Berut & $8 \mathrm{NI} 0128911992$ \\
\hline
\end{tabular}

\subsection{Media Perawatan Benda Uji}

Media perawatan benda uji menggunakan 3 jenis air yaitu air laut, air payau dan air rob. Pengujian ketiga media perawatan disajikan pada Tabel 4.3.

Tabel 4.3. Hasil Pengujian Laboratorium Media

\begin{tabular}{|c|c|c|c|c|}
\hline & \multicolumn{4}{|c|}{ Perawatan } \\
\hline \multirow[t]{2}{*}{ No } & \multirow[t]{2}{*}{ Parmeter } & \multicolumn{2}{|c|}{ Hasil } & \multirow{2}{*}{ Metode Aaslisis } \\
\hline & & Alr Tawar & Ait Laot & \\
\hline 1 & Klonida (mg I) & 21,09 & - & SSI $06-2474-1991$ \\
\hline 2 & Sulfat(ing1) & 13 & - & SN1 6989.20:2009 \\
\hline 3 & Salfída (mgl) & - & 0,072 & 5xt $6989.70-2009$ \\
\hline 4 & Timbal $(m g)$ & . & 0,58 & SNI $06-6939.51-2005$ \\
\hline 5 & Ph. & 7,93 & 7,11 & SNT $06-6989.11-2004$ \\
\hline
\end{tabular}

\subsection{Hasil uji bahan}

Dengan berat volume pasir adalah $1,02 \mathrm{~kg}$, hasil pengujian agregat halus mendapat hasil :
a. Kadar lumpur $=3,84$
b. Berat jenis kondisi kering $=2,68$
c. Berat jenis kondisi SSD $=2,78$
d. Prosentase penyerapan Air $=3,76 \%$

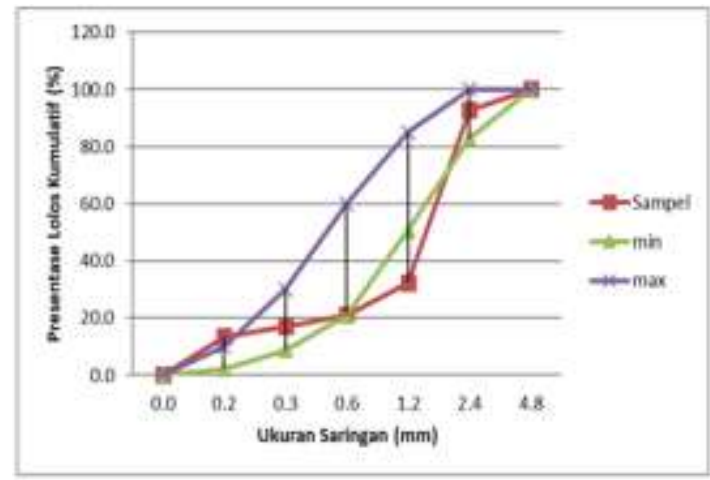

Gambar 4. 1 Gradasi Agregat Halus

\subsection{Hasil Uji Kuat Tekan}

Berikut ini merupakan perbandingan kuat tekan rata-rata dari semua campuran yang dibuat dengan 3 jenis media perawatan menggunakan air laut, air payau, maupun air Rob

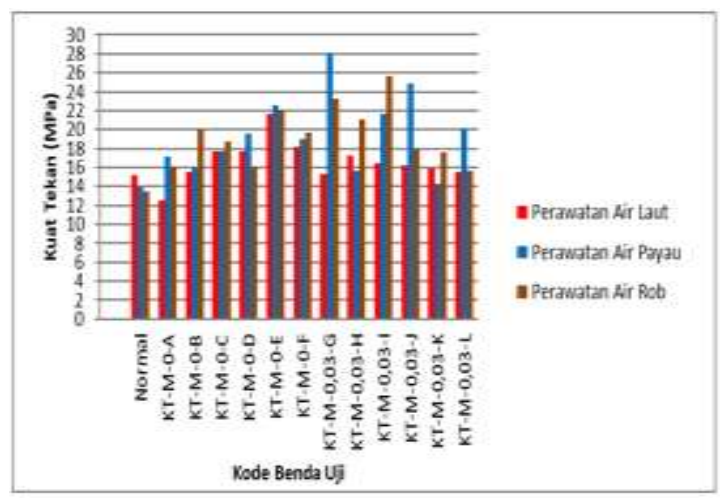

Gambar 4. 2 Perbandingan Kuat Tekan RataRata Benda Uji Umur 7 Hari

Pada umur 7 hari, benda uji yang memiliki kuat tekan paling tinggi ada pada benda uji KT-M-0-G yang dirawat dengan air payau dengan bahan madu $0,03 \%$ dari berat semen dan amylum $0,1 \%$ dari berat semen pada umur 7 hari, mortar belum mengalami pengerasan yang sempurna. Kadar garam yang ada dalam 3 jenis air yang digunakan sebagai media perawatan dapat menyebabkan larutnya senyawasenyawa yang ada didalam mortar tersebut (bleaching). Dalam waktu yang singkat, proses ini dapat membantu mortar untuk menjadi lebih padat, akan tetapi mungkin akan merusak struktur dari mortar tersebut jika terjadi pada proses yang lama. 


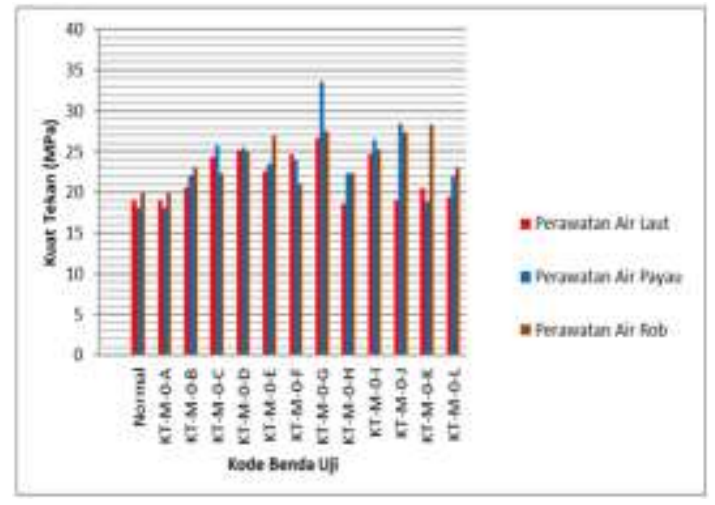

Gambar 4. 3 Perbandingan Kuat Tekan RataRata Benda Uji Umur 14 Hari

Pada umur 14 hari, benda uji yang dirawat dengan air payau memiliki kuat tekan yang paling tinggi yaitu pada benda uji KT-M-0-G dengan bahan madu $0,03 \%$ dari berat semen dan amylum $0,1 \%$ dari berat semen.

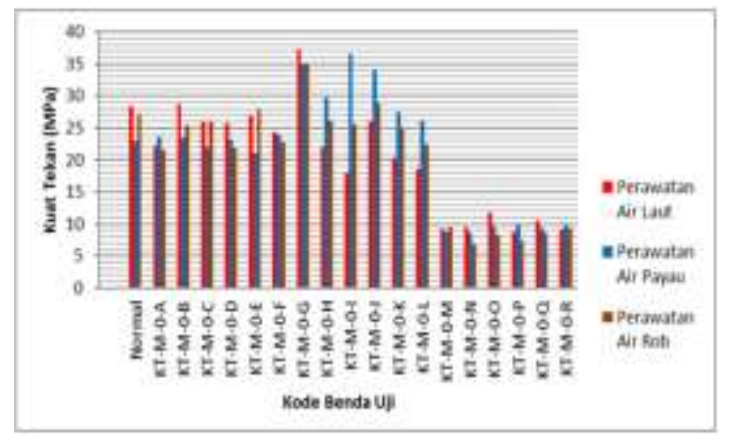

Gambar 4. 4 Perbandingan Kuat Tekan Rata-Rata Benda Uji Umur 28 Hari

Pada umur 28 hari, benda uji yang dirawat dan dirawat dengan media perawatan air laut memiliki kuat tekan yang paling tinggi yaitu pada benda uji KT-M-0-G dengan bahan madu $0,03 \%$ dari berat semen dan amylum $0,1 \%$ dari berat semen.

sampai dengan umur 28 hari, terjadi perubahan yang cukup terlihat dimana saat umur 7 hari dan 14 hari, benda uji yang dirawat dan dirawat dengan air laut nilai kuat tekannya lebih rendah jika dibandingkan dengan benda uji yang dirawat dengan 2 jenis media perawatan lain. Akan tetapi, pada umur 28 hari, benda uji yang dirawat dengan air laut nilai kuat tekan rata-ratanya lebih tinggi dibandingkan dengan yang lain.

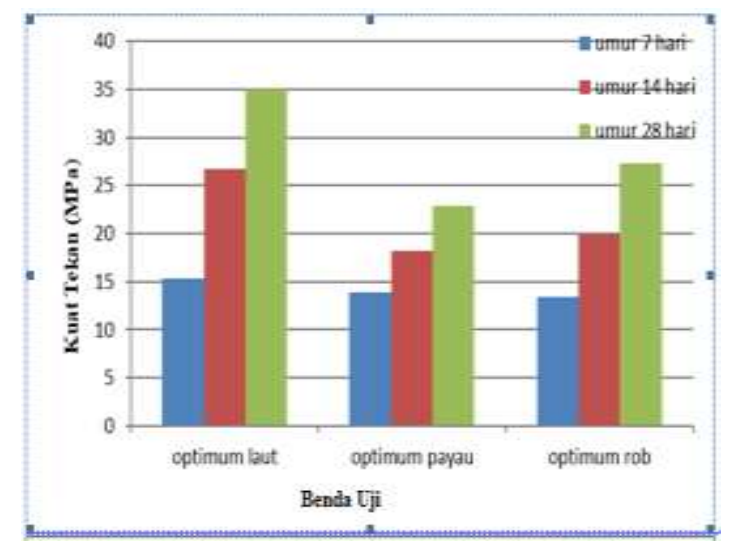

Gambar 4. 5 kuat tekan optimum dari masing masing jenis media perawatan

Jika dilihat dari Gambar 4.5 diatas akan terlihat bahwa benda uji yang memiliki kuat tekan optimum dari keseluruhan adalah benda uji yang memiliki kuat tekan optimum pada benda uji yang dirawat menggunakan air laut yaitu KT-M-0-G

\section{Kesimpulan dan Saran 5.1. Kesimpulan}

a. Penggunaan madu dan amylum sebagai bahan tambah mortar polimer dengan kadar tertentu mengahsilkan kuat tekan yang lebih tinggi dibanding mortar normal, dengan persentase kuat tekan mortar normal 39,53\% dan persentase kuat tekan mortar dengan bahan tambah sebesar $60,47 \%$.

b. Komposisi dengan madu $0,03 \%$ dan amylum $0,1 \%$ dari berat semen yang dirawat dengan air laut merupakan komposisi yang memiliki kuat tekan paling tinggi yaitu $37,36 \mathrm{MPa}$.

c. Nilai kuat tekan optimum terdapat pada benda uji dengan madu $0,03 \%$ dan amylum $0,1 \%$ yang dirawat dan dirawat air laut karena peningkatan kuat tekan dari umur 7 hari sampai 28 hari paling signifikan dibandingkan dengan benda uji lain yang memakai media perawatan lain. Persentase umur 7 hari 19,25\%, 
umur 14 hari 33,67, dan umur 28 hari sebesar $47,08 \%$.

d. Campuran bahan tambah madu 0,3\% dari berat semen bukan merupakan campuran yang baik dikarenakan keseluruhan dari benda uji dengan campuran tersebut memiliki nilai kuat tekan yang sangat rendah, bahkan sebelum usia 20 hari, benda uji masih sangat rentan hancur.

e. Menambahkan madu dan amylum terlalu banyak pada campuran mortar akan menghasilkan hasil yang kurang baik. Sebaliknya jika terlalu sedikit tidak akan berpengaruh terlalu besar pada hasil kuat tekan mortar tersebut.

\subsection{Saran}

a. Penggunaan bahan tambah madu dan amylum sangat prospektif untuk dikembangkan sebagai bahan tambah karena sudah terbukti meningkatkan kuat tekan.

b. Perlu dilakukan riset lain terkait komposisi optimum lain ataupun pengujian lebih lanjut untuk komposisi madu $0,3 \%$.

\section{Daftar Pustaka}

ACI 201.2R - 01, "Guide to Durable Concrete," ACI Committee 201 on Durability of Concrete

Anggraeni Syindi Salmani. (2014). Pengaruh Kadar Zat Additive Terhadap Kuat Tekan pada Beton mutu Tinggi. Fakultas Teknik. Universitas Lampung. Lampung. http://digilib.unila.ac.id/2137/ diakses 2014.

Arif. dkk (2015), "Pengaruh Resin Epoksi Terhadap Mortar polimer Ditinjau dari Kuat Tekan, Kuat Tarik Belah, Daya Serap Air dan Scanning Electron Microscope.

Budianto, A.K., (2009). Dasar - Dasar Ilmu Gizi. UMM Press. Malang.

Dian Yunita Simanullang. (2014).Kajian Kuat Tekan Mortar Menggunakan Pasir Sungai dan Pasir Apung dengan Bahan Tambah Fly Ash dan Conplast dengan Perawatan (Curing), Skripsi, Fakultas Teknik, Universitas Sriwijaya. Sumatera Selatan.

Hudallah Muhammad F. (2011). Durabilitas Beton Yang Mengandung Fly Ash Untuk perkerasan kaku Yang Tahan Terhadap Air Laut.Fakultas Teknik Sipil. Universitas Sebelas Maret. Surakarta.

Murdock dan K.M Brook (Alih bahasa Stepanus Hendarko). (1991). Bahan dan Praktek Beton. Jakarta; Erlangga

Neville, A.M. dan Brooks, J.J. (1987). Concrete Technology. New York: Longman Scientific \& Technical.

Nugraha \& Antoni. (2007). Teknologi beton. Surabaya: Andi

Saepudin, UU. (2011). Desain Bahan Perkuatan Perkerasan Kaku Dengan Over Slabbing. Magister Teknik Sipil. Universitas Sebelas Maret. Surakarta.

Susilorini, Rr. M. I. Retno. (2007). Model Masalah Cabut-Serat Nylon 600 Tertanam dalam Matriks Sementitis yang Mengalami Fraktur, Disertasi, Unika Parahyangan, Bandung.

Susilorini, Rr. M. I. Retno. (2007). Model Masalah Cabut-Serat Nylon 600 Tertanam dalam Matriks Sementitis yang Mengalami Fraktur, Disertasi, Unika Parahyangan, Bandung.

Susilorini, Rr. M.I. R, Suwarno, DJ., Santosa, B. (2017). Strategi Adaptasi Masyarakat Pesisir Semarang dan Demak untuk Mitigasi Pengurangan Resiko Bencana Banjir dan Rob Akibat Perubahan Iklim, Semarang, Laporan Akhir, INSINAS RPI, Tahun Pertama, DPTI, Kemenristekdikti. 